\title{
Working Capital Management Effect on the Performance of Wholesale and Property Industry in Malaysia
}

\author{
Lee Hui Shan*, Har Wai Mun, Yow Taw Onn, Lee Sin Yee, Sim Kee Chuan \\ Universiti Tunku Abdul Rahman, Selangor, Malaysia \\ Universiti Putra Malaysia, Selangor, Malaysia \\ *hslee@utar.edu.my
}

\begin{abstract}
This paper provides the influence of working capital management (WCM) on the performance of public listed wholesale \& retail industry and property industry in Malaysia from 2002 to 2011. Regression model is employed by using two measures of companies' performance namely Return on Assets, ROA (proxy to gauge the firm's profitability) and Tobin's Q, TQ (proxy to gauge the firm's market value) as the dependant variables. WCM components include Current Liabilities to Total Assets Ratio and Current Assets to Total Assets Ratio with three control variables which include of Firm Size (SIZE), Sales Growth (SLGR) and Financial Leverage (LEV) as the independent variables. The results to a very large extent indicate that CATAR and SIZE have significant positive effect on the performance of firm. It suggests that wholesale \& retail industry and property industry in Malaysia should pursue unadventurous investment strategy by implementing high altitude of short term investment in order to make profit and create value for their shareholders. It also reveals that the larger the firms are, the more profitable they are; recommending the firms shall expand their business to achieve higher profit and accomplish shareholder wealth maximisation.
\end{abstract}

Keywords: Working capital management, return on assets, Tobin's Q, current ratio, firm size

\section{Introduction}

Working Capital Management (WCM) engages crucial function as an element of venture in asset that needs suitable financing strategy. As reported by Sanger in 2001, WCM operated as a constraint in financial performance as it engages short term financing and do not contribute to return on equity. This leads to lack of attention on WCM in financial decision making. Hence, to ensure a smooth operating cycle of the business, it is crucial for firms to maintain their short term investment. Thus, the main concern of WCM is to make sure that the organisation has enough cash flow to brighten up both upcoming operational expenses and maturing short-term debt to sustain its operations. Kargar \& Blumenthal (1994) examined that a miss-management in working capital can make a firm goes bankrupt even the financial performance is earning profit. To strive desired trade-off between liquidity and profitability always become a dilemma in WCM (Smith, 1980; Raheman and Nasr, 2007). As mentioned in assumption of risk and return, a policy of investment with high risk will promise higher return while investment with low risk will give lower return. Therefore, firms with low risk and low return will have WCM with high liquidity whereas firms that have WCM with low liquidity will be facing a higher risk that might result a higher profitability. The problem in WCM is the firm must consider how to stabilise among risk and return.

The concern of this paper is aiming to analyse the influence of WCM towards the performance of public listed wholesale \& retail companies as well as property companies in Malaysia. Three motivations give rise to this study. Firstly, Alam, Ali, Rehman and Akram (2011) each sector of the economy should be targeted and avoid a randomly collection because pas literatures revealed significant support that the ratios of working capital are different for dissimilar industries. This concern also raised by Pouraghajan and Emamgholipourarchi (2012). Secondly, Lazaridis and Tryfonidis (2006) proposed that different variables of practices and external variables should be included in order to provide strong relationship between WCM and firms' performance. Thirdly, previous researches centre on the develop market (Shin \& Soenen, 1998 and Deloof, 2003) where they could have stronger WCM compared to emerging market. Therefore, supplementary studies and diverse indication on the WCM to improve finance literature about WCM could be gained by investigating WCM in emerging market such as Malaysia and focusing on the firms by segmental with additional control variables. 
Furthermore, the results of this study would give decision maker in the firm for better insights on how to create an efficient WCM which contributes to maximising firm's value to build up confidence among the investors in order to convince investors to invest in their firms. With this, the investors will invest in Malaysia confidently which will eventually groom the economic and help the managers to apply innovative sets of stronger plans on the WCM to ensure there is enhancement in the growth of Malaysia's economic.

\section{Literature Review}

In Belgium firms, according to Deloof (2003) established significant inverse relationship between gross income and (i) the number of days accounts receivable (AR), (ii) inventories and (iii) accounts payable. It is believed by reasonably reducing the number of account receivables (AR) days and inventories, managers could make benefit for shareholders. Eljelly (2004) examined the connection between profitability and liquidity in Saudi Arabia. To gauge the profitability and liquidity level, Current Ratio (CR) and cash gap or Cash Conversion Cycle (CCC) were used and instituted that there were significant inverse relationship between the both levels. This affiliation becomes more evident in firms with high CR and higher CCC. The study also criticised that excessive liquidity could be the unnecessary costs that lead to lose of profits.

Nazir and Afza (2009) used non-financial companies from 1998 to 2005 listed on the Karachi Stock Exchange (KCE) to consider the link between WCM policies and profits of the organisations. The dependent variables of this study are Return on Assets (ROA) and Tobin's Q, whereas the independent variables include Total Current Assets to Total Assets Ratio (TCA/TA) and Total Current Liabilities to Total Assets Ratio (TCL/TA). Furthermore, the control variables of this study include the size of the firm (SIZE), growth of the firm (GROWTH), financial leverage (LVRG) and real annual GDP growth (GDPGR). Based on the results obtained from this study, there is a negative link between TCA/TA and profit of the organisation which further indicated that firms should pursue conservative investment policy to increase firms' profitability and value. In addition, this study also indicated that there is a negative link between TCL/TA and a firm's profitability. However, the study showed a positive link between TCL/TA and a firm's value. These results show that while aggressive financing policies have a bad consequence on a firm's profitability, they do have a positive influence on the value of the organisation. Investors typically invest in the shares of companies that apply an aggressive behavior in handling their liabilities in short term. Moreover, the findings of this study indicated that GROWTH and LVRG have a significant relationship with the book-based ROA. Such an indication confirmed the strong correlation LVRG and GROWTH have with the book value-based performance measured. Lastly, the findings of this study shows that the returns based on book value may not be affected by GDPGR but a position change in the level of economic activity may cause it to react positively.

A study done by Zariyawati et al. (2009) studied the correlation between WCM and the profitability of Malaysian firms for 11 years since 1996 to 2006 which employs (Operating Income + Depreciation)/Total Assets (OI) as a measure for profitability. Furthermore, CCC which is used in this study as a measure of WCM and the growth in firms' sales (SG) along with leverage are the two control variables of this study. A Pooled OLS regression analysis of this study shows results that indicate a significant negative correlation between CCC and a firm's profitability. Therefore, a firm's manager should take into careful consideration the reduction of cash conversion period with the intention of creating and maximizing profit for shareholders. Ray (2012) conducted an investigation on the link between WCM components and the Indian manufacturing firms' profit which were drawn from a sample of Indian manufacturing firms that have existed since 19961997 to 2009-2010. This investigation includes variables such as inventory turnover in days, average payment period, average collection period, CCC and current ratio, size of the firm, debt ratio and financial assets to total assets ratio on the net operating profits. According to the results of this investigation, there is a strong negative relationship between the measures of WCM which includes the number of days that accounts are receivable and CCC, financial debt ratio with corporate profitability. These results show that the longer the period of collection for accounts receivables, the lower the profitability of the firms. This negative link between the profit of an organisation and CCC indicates that the longer the CCC, the smaller the profitability of a firm. In addition, the results of this study also illustrated that there is an insignificant negative relationship between the net operating profit ratio of a firm and its size. Hence, the results of this study advise managers to create value for their investors by minimising the number of days given for AR. Furthermore, less profitable firms are likely to reduce their AR to decrease cash gap in CCC due to the negative relationship 
between firms' profitability and AR. To conclude, when a firm manages their working capital efficiently, the profit of the organisation will be improved. These results propose that value can be built by managers for investors when the number of days given for a reasonable minimum accounts receivable.

Charitou, Lois and Santoso (2012) studied firms that were listed on the Indonesian Stock Exchange during 1998 to 2010. By using firms from various industry including Tobacco, Retail and Wholesale, Food and Beverages and Apparel, they found out that CCC and Net Trade Cycle had a negative impact on a firm's profitability. Besides, it also showed the riskiness of a firm, measure by debt ratio, has a negative correlation to the firm's Return on Assets. This result suggested that by taking advantage of credit terms to suppliers, it creates a positive value to the market. Besides, a firm will also need to maintain their inventories at an appropriate level where it is enough to satisfy clients but not too low to avoid losing them. As long as clients' credit terms are concerned, the firm will remain competitive to keep their existing clients as well as attract new clients. There was a similar study in Pakistan conducted by Afeef (2011) to find out the potential effect of WCM on Small and Medium-size enterprise (SME) profit performance. The main intention of the study was to formulate an empirical relationship between WCM and profitability of SME that were listed on Karachi Stock Exchange. In addition, by using a sample of 40 firms between 2003 and 2008, a total of 240 firm-year observations, this paper aimed to analyze a few component of WCM on SMEs' profitability using Return on Assets (ROA) and Operating Profit to Sales (OPS) to measure the firms' profitability. ROA and OPS are the dependent variables and CCC, RCP, ICP, PDP and CR are the independent variables whereas other variables such as Natural Logarithm of Sales, Sales Growth and Financial Leverage measure the efficiency of WCM. The result were, (i) strong negative relationship of ICP and RCP with the OPS of smaller firms; (ii) no significant associations between firm's profitability and PDP, CCC and C; (iii) no significant association between WCM with liquidity and ROA; and (iv) no significant relationship of firm's profitability with PDP and CCC, but a firm's profitability has association with ICP and RCP.

Different from Afeef (2011) sample selection, Usama (2012) focused on "non-food related stocks in the Karachi Stock Exchange. Data covered 18 companies and six years from 2006 to 2012. Usama (2012) examined the effect of different variables of WCM such as Average Payment Period (APP), Average Collection Period (ACP), Cash Conversion Cycle (CCC), Inventory Turnover in Days (ITID), Debt Ratio (DR), Current Ratio (CR), Financial Assets to Total Assets Ratio (FATA), and Net Operating Profitability (NOP) using pooled least square regression and common effect model. From the study it is found that (i) there was a significant direct effect of WCM on profitability and liquidity of the organisations; and (ii) Size of the Firm which was gauged in terms of natural logarithm of sales (LOS) and FATA had significantly direct effect on firm's profitability. Hence, this research on the wholesale \& retail and property industries in Malaysia by using latest research in the market models is another extension to the WCM theory in response to the profitability and market value of the firms.

\section{Methodology}

Sample of 204 companies in wholesale \& retail sector and property sector listed in Bursa Malaysia are selected in this study as both sectors contribute to the economy growth in Malaysia. ${ }^{1}$ The sample comprises of 124 companies from wholesale \& retail industry and 80 companies from property industry. The data of

\footnotetext{
${ }^{1}$ Economic Transformation Programme has 12 National Key Economic Areas, Wholesale \& retail industry is one of it. It is forecasted that wholesale \& retail industry in Malaysia will create 454,190 new jobs and boost the Gross National Income (GNI) by RM156 billion by 2020. Retail contributed RM100.6 billion and RM114.4 billion to GNI in 2010 and 2011 respectively. It is the fourth biggest contributor to GNI (JabatanPerdanaMenteri, 2012).

The population of those below the age of 30 is around $60 \%$ and this is a group of potential first house buyers. The 10 -year population growth rate is at $2.2 \%$. This is a reason for the growth in residential properties estimated to be strong in Malaysia (Afiq, 2012). Furthermore, according to According to Nor, Nurhisham and Afiq (2012), anecdotal evidence suggested that the potential of the property sector is quite encouraging. The sales of the property has risen from RM61 billion in 2006 to RM138 billion in 2011. The rising incomes, living standards, greater urbanisation and the favourable demographics of the population in Malaysia have led to strong performance of the property sector.
} 
each company are extracted from the annual reports respectively. Samples with missing data during the study period (2002 to 2011) are excluded. Panel data regression model is employed by using two measures of company's performance namely Return on Assets, ROA (proxy to measure company's profitability) and Tobin's Q, TQ (proxy to measure the company's market value) as the dependant variables. Return on Assets $(\mathrm{ROA})$ is measured as below:

$$
R O A=\frac{\text { Income Available to Common Equity or Net Income }(N I)}{\text { Mode Of Total Assets or Average Total Assets (ATA) }}
$$

ROA is the ratio of the Net Income (NI) to the Average Total Assets (ATA). ATA is the average of the values of Total Assets (TA) from the company's balance sheet in both the beginning and end of each fiscal period. ROA shows the profitability of a company before leverage and is compared with companies in the same industry and commonly acknowledged as reflection on the efficiency of management generate earnings from its assets. Tobin's Q (TQ) is measured as below:

$$
T Q=\frac{\text { Total Market Value of Firm (MVF) }}{\text { Total Assets (TA) }}
$$

Tobin's Q (TQ) is the ratio of the Total Market Value of Firm (MVF) to the Total Assets (TA). The MVF is calculated by adding up the Market Capitalization, Liabilities, Preferred Equity and Minority Interest. It is computed as the product of company's closing price and the shares outstanding. If the stock is undervalued, the Tobin's $Q$ will be low, between 0 and 1 . This shows that the cost to replace a company's assets is larger than the value of its share. Two components of WCM (WCM) are used as independent variables. They are the ratio of Current Assets to Total Assets (CATAR) and the ratio of Current Liabilities to Total Assets (CLTAR). The independent variables used here are in consistent with previous study by Nazir and Afza (2009), Raheman, Afza, Qayyum and Bodla (2010), Azam and Haider (2011), Mona (2012), Kaddumi and Ramadan (2012), Vahid, Mohsen and Mohammadreza (2012), Hussain, Farooq and Khan (2012) and Pouraghajan and Emamgholipourarchi (2012). The CATAR is computed as below:

$$
\text { CATAR }=\frac{\text { Current Assets }(C A)}{\text { Total Assets }(T A)}
$$

This ratio basically shows the share of current assets investment to total investment in assets. Thus, it reflects the structure of assets and the amount in form of current assets per each ringgit invested in assets. If the CATAR shows positive sign, this means that the company invest a large portion on short term investment to increase the company's performance. This is a conservative investment policy. An aggressive investment policy is to invest a minimum level in Current Assets (CA) versus fixed assets and vice versa. Thus, for the management with conservative approach, the level of CA increases in proportion to the TA of the company (Nazir and Afza, 2009; Mona, 2012 and Vahid, Mohsen and Mohammadreza, 2012). Total Assets (TA) are listed on a company's balance sheet and represents everything that a business owns. In short, Total Assets (TA) are the sum of all investments, equipments, receivables, cash, intangibles, fixtures, furniture and any other items of value that owned by a business entity. Current Liabilities to Total Assets Ratio (CLTAR) is computed as below:

$$
\text { CLTAR }=\frac{\text { Current Liabilities }(C L)}{\text { Total Assets }(T A)}
$$

CLTAR can be computed by dividing the Current Liabilities (CL) with the Total Assets (TA). CLTAR is a financial ratio used to show the percentage of a company's assets that are provided through debt. A CLTAR of less than 0.5 indicates that the company's assets are mostly financed through equity and indicates lowly leveraged. Companies with higher levels usage of CL and less long-term debt are putting their liquidity on risk. This is an indication of aggressive financing policy (Nazir and Afza, 2009; Mona, 2012 and Vahid, Mohsen \& Mohammadreza, 2012). There are three control variables or moderating variables which include Firm Size (SIZE) Sales Growth (SLGR) and Financial Leverage (LEV). These control variables are in accordance with the previous study by Deloof (2003), Teruel and Solano (2007), Nazir and Afza (2009), Raheman, Afza, Qayyum and Bodla (2010), Afeef (2011), Mona (2012), Vahid, Mohsen and Mohammadreza (2012), Hussain, Farooq and Khan (2012) and Charitou, Lois and Santoso (2012). Firm Size (SIZE) can be measured as:

$$
\text { SIZE }=L N(\text { Total Assets })=L N(T A)
$$


SIZE is computed by taking the natural logarithm of total assets (LN TA). By taking the natural logarithm of total assets (LN TA) the heteroscedasticity and influences of outliers in the regression model can be reduced. Sales Growth (SLGR) is computed as below:

$S L G R=\frac{\text { Sales } t-\text { Sales } t-1}{\text { Sales } t-1}$ Or $\quad S L G R=\frac{\text { Net Sales for the Current Period }}{\text { Net Sales for the Last Period }}-1$

SLGR is calculated but taking the net sales for the current period deducts the net sales for the previous period and the value from the deduction is divided by the net sales from the last period. Financial Leverage (LEV) is measured as below:

$$
L E V=\frac{\text { Average Total Asstes }(A T A)}{\text { Average Total Common Equity }(A T C E)}
$$

LEV is calculated by dividing the Average Total Assets (ATA) with the Average Total Common Equity (ATCE). The computation for LEV used in this study is not in accordance to the previous studies. High degree of LEV will yield to a high interest payments and cause the firms to face the risk of bankruptcy if the firms are unable to make payments on their debt. Multiple linear regression analysis is applied to determine the association between independent and control variables with dependent variables (Hussain, Farooq and Khan, 2012). Fixed effects model is used. It presumes a specific intercepts and the impacts of all determinants on each firm which are constant over time are captured (Raheman, Afza, Qayyum and Bodla, 2010). For data processing and statistical tests, SPSS 20 are used. The regression models are:

$$
\begin{gathered}
\mathrm{ROA}=\mathrm{a}+\beta 1(\mathrm{CATAR})+\beta 2(\mathrm{CLTAR})+\beta 3(\mathrm{SIZE})+\beta 4(\mathrm{SLGR})+\beta 5(\mathrm{LEV})+\varepsilon_{\mathrm{i}} \\
\text { (Equation } 1)
\end{gathered}
$$$$
\mathrm{TQ}=\mathrm{a}+\beta 1(\mathrm{CATAR})+\beta 2(\mathrm{CLTAR})+\beta 3(\mathrm{SIZE})+\beta 4(\mathrm{SLGR})+\beta 5(\mathrm{LEV})+\varepsilon_{\mathrm{i}}
$$

\begin{tabular}{|c|c|}
\hline a & $=$ Intercept \\
\hline ROA & $=$ Return on assets of firm i for time period $t$ \\
\hline TQ & $=$ Market value of firm i for time period $t$ \\
\hline CATAR & $=$ Current assets to total assets ratio of firm i for time period $t$ \\
\hline CLTAR & $=$ Current liabilities to total assets ratio of firm i for time period \\
\hline SIZE & $=$ Firm size, natural logarithm of firm's total assets $(\ln T A)$ \\
\hline SLGR & $=$ Sales growth or growth of annual sales \\
\hline LEV & $=$ Financial leverage of firms \\
\hline & $=$ Error term of the model \\
\hline
\end{tabular}

$$
\text { (Equation 2) }
$$

Where:

\section{Results and Discussion}

Return on Assets (ROA): The result of linear regression analysis for Equation 1 (ROA) are shown in Table 1a and $1 \mathrm{~b}$ for combine wholesale \& retail and property industry. Its regression equation is as below:

$\mathrm{ROA}=-0.027+0.088 C A T A R+0.001 S L G R-0.00001 L E V-0.112 C L T A R+0.008 S I Z E$

(S.E) $(0.009)^{* * *}(0.010)^{* * *} \quad(0.001) \quad(0.000) \quad(0.004)^{* * *}(0.001)^{* * *}$

${ }^{* * *}$ indicates significant at $1 \%$; S.E. is standard error)

The result shows that CATAR and SIZE have positive effect on ROA while CLTAR has negative effect on ROA at $1 \%$ of significant level. SLGR and LEV are not significant. Positive coefficient of CATAR implies that firm wholesale \& retail and property industries in Malaysia pursued conservative investment policy by having high level of short term investment in order to increase firm's profitability. This result indicates that both industries investment strategy was to maintain the real value of the business against inflation to ensure a desirable profit. This result is in confirmation with the findings conducted by Nazir and Afza (2009), Raheman, Afza, Qayyum and Bodla (2010), Pouraghajan and Emamgholipourarchi (2012) and Mona (2012) who also found conservative investment policy had positive effect on firm's profitability. Negative coefficient of CLTAR shows that both wholesale \& retail and property industries implemented aggressive financing policy by using more short term debt to finance their operating activities and this strategy had negative effect on firm's performance. This result is in consistent with the findings made by Nazir and Afza (2009), Raheman, Afza, Qayyum and Bodla (2010), Pouraghajan and Emamgholipourarchi (2012), Mona (2012), Hussain, Farooq and Khan (2012) and Vahid, Mohsen and Mohammadreza (2012). The reason that both industries 
chosen to use short term financing such as raising fund through stock market rather than bond market is to avoid paying interest periodically to the bondholder. Unlike in the stock market, the decision to pay dividend to the stockholders is at the firm's discretion. However, the result has indicated that both firms strategy by using short term financing policy will hamper their profit.

Positive coefficient of SIZE implies that larger firms are more profitable. This result is in conjunction with the previous study conducted by Deloof (2003) and Vahid, Mohsen and Mohammadreza (2012). The result proposes that both wholesale \& retail and property industries in Malaysia are expanding, and the expansion of their business could enhance their profitability. This is a good indicator wholesale \& retail industry's strategy moved in line with Malaysia's Economic Transformation Plan in promoting wholesale \& retail industry and both industries supporting Malaysia's Government Transformation Programme to grow soundly in achieving Malaysia's 2020 Vision to become a developed nation (Jabatan Perdana Menteri, 2010 and 2012). Insignificancy of SLGR and LEV is consistent with Charitou, Lois and Santoso (2012) and Usama (2012) respectively. Insignificant SLGR suggests that increasing in sales do not provide a promising profit to the firms. This advocate that both industries shall not only focus on marketing strategy to boost their sales but also should focus on the management issue with the ambition to generate profitability. Insignificant of LEV suggests that they did not focusing on bond market which did not result them to have commitment in interest payment and as the consequence high leverage did not show significant affect to their profit. This result support suggestion as mentioned in CLTAR discussion where both industries are focusing in stock market in raising fund.

Table 1: Linear Regression Results from the Combination of Wholesale \& Retail and Property Industries (Model Summaryb)

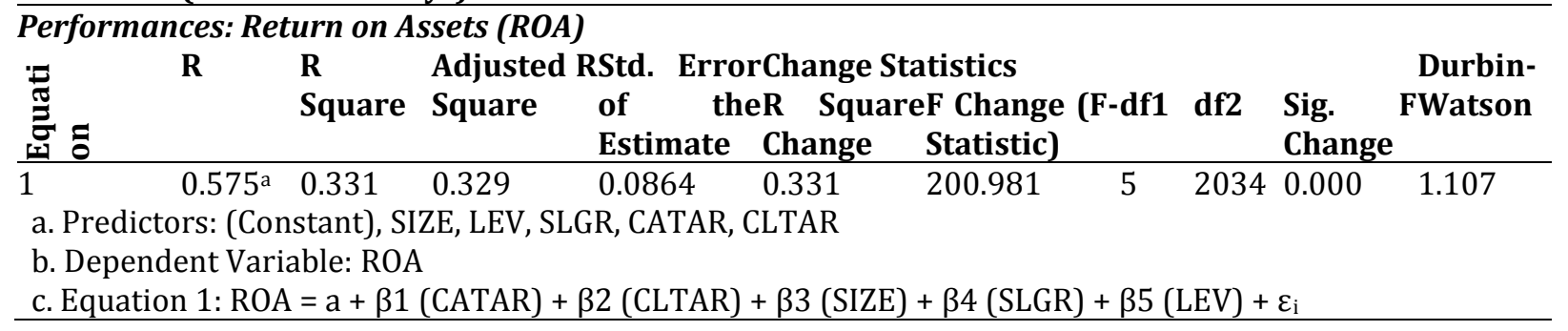

Table 2: Linear Regression Results from the Combination of Wholesale \& Retail and Property Industries(Coefficientsa)

\begin{tabular}{|c|c|c|c|c|c|c|}
\hline \multicolumn{2}{|c|}{$\begin{array}{l}\text { Performances: Return on Assets (ROA) } \\
\text { Independent \& } \\
\text { Control Variables }\end{array}$} & \multicolumn{2}{|c|}{$\begin{array}{l}\text { Unstandardized } \\
\text { Coefficients }\end{array}$} & $\begin{array}{l}\text { Standardized } \\
\text { Coefficients } \\
\text { Beta }\end{array}$ & $\mathbf{t}$ & Sig. \\
\hline & (Constant) & -0.027 & 0.009 & & -3.003 & 0.003 \\
\hline & CATAR & 0.088 & 0.010 & 0.167 & 9.043 & 0.000 \\
\hline & SLGR & 0.001 & 0.001 & 0.020 & 1.106 & 0.269 \\
\hline & LEV & $-9.211 \mathrm{E}-006$ & 0.000 & -0.006 & -0.326 & 0.745 \\
\hline & CLTAR & -0.112 & 0.004 & -0.553 & -29.844 & 0.000 \\
\hline & SIZE & 0.008 & 0.001 & 0.114 & 6.231 & 0.000 \\
\hline
\end{tabular}

The regression equation for Equation $1(\mathrm{ROA})$ for wholesale \& retail industry is as below:

ROA $=-0.042+0.097 C A T A R+0.035$ SLGR $-0.001 L E V-0.201 C L T A R+0.018 S I Z E$

(S.E) $(0.011)^{* * *}(0.014)^{* * *} \quad(0.005)^{* * *}(0.000)^{* * *} \quad(0.014)^{* * *} \quad(0.002)^{* * *}$

(*** indicates significant at 1\%; S.E. is standard error, Adjusted R square is 0.226 and F-stats significant)

The regression equation for Equation 1 (ROA) for property industry is as below:

$\mathrm{ROA}=-0.018+0.049$ CATAR $+0.0003 S L G R+0.000005 L E V-0.104 C L T A R+0.006 S I Z E$

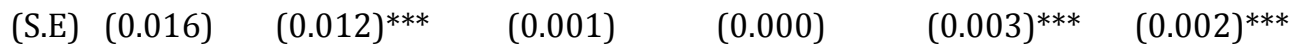

(*** indicates significant at $1 \%$; S.E. is standard error, Adjusted R square is 0.61 and F-stats significant) 
Result from property industry regression is consistent with results from combine both wholesale \& retail and property, where CATAR and SIZE are positive-significant, CLTAR is negative-significant while SLGR and LEV are not significant. For wholesale \& retail, both SLGR and LEV are significant at $1 \%$ level. This result has proven that wholesale \& retail industry depended on sales to achieve profit but property industry did not highly depend on sales to increase profit.

Tobin's Q (TQ: The results of linear regression analysis for Equation 2 (TQ) are shown in Table 3 and 4 for combine wholesale \& retail and property industry. Its regression equation is as below:

$\mathrm{TQ}=-0.155+0.517$ CATAR -0.014 SLGR $+0.00008 L E V-0.022$ CLTAR +0.099 SIZE

(S.E) $(0.078)^{* *}(0.086)^{* * *} \quad(0.010) \quad(0.007) \quad(0.033) \quad(0.012)^{* * *}$

(*** indicates significant at $1 \%,{ }^{* *}$ significant at $5 \%$; S.E. is standard error)

The result shows that CATAR and SIZE have positive effect on ROA at 1\% level while LEV, SLGR and CLTAR are not significant. Positive coefficient of CATAR implies that firm should adopt prudent working capital investment strategy in order to create value for shareholders' wealth. This result is consistent with the research conducted by Nazir \& Afza (2009) and Mona (2012) that suggested a negative affiliation between aggressive investment policy and firm's value (TQ). The result proposes that both firms' strategy on conservative investment to expand their business had attracted the confidence of stockholders, hence increase their market value. Positive coefficient of Firm Size (SIZE) implies that larger firms are more profitable. This result is in confirmation with the previous study conducted by Nazir and Afza (2009), Mona (2012) and Vahid, Mohsen and Mohammadreza (2012) who also found size of the firm had positive effect on firm's performance (TQ). Increasing of the wholesale \& retail and property industries provides an indicator that Malaysia is doing reasonably well and the economic growth is stable that giving them the opportunity in expanding the business.

Table 3: Linear Regression Results from the Combination of Wholesale \& Retail and Property Industries (Model Summaryb)

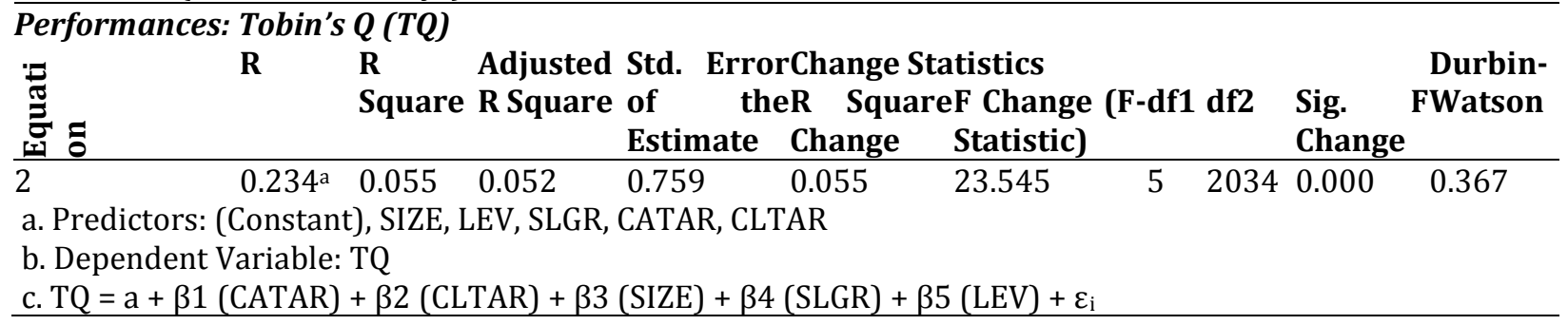

Table 4: Linear Regression Results from the Combination of Wholesale \& Retail and Property Industries(Coefficientsa)

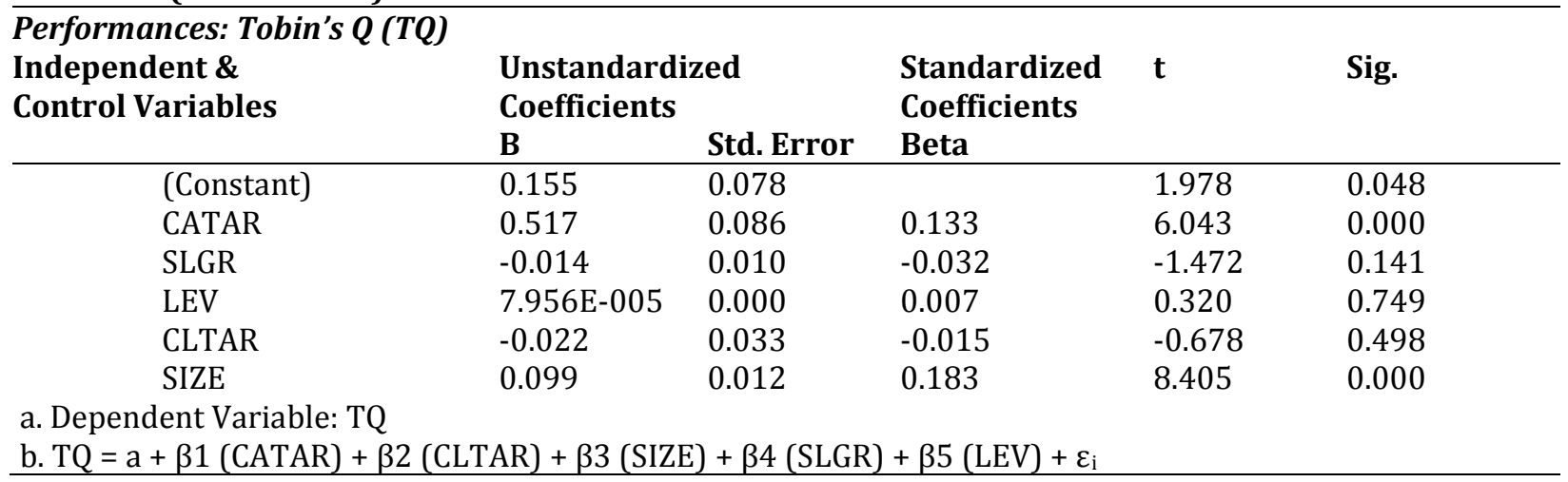

Result of SLGR is not significant which is consistent with Nazir and Afza (2009) and Mona (2012). This suggests that the shareholders did not focusing on the sales of the firms and their major objective is to achieve their wealth maximisation. The insignificant result of LEV is consistent with Pouraghajan and Emamgholipourarchi (2012). The insignificant result of CLTAR is consistent Pouraghajan and 
Emamgholipourarchi (2012). This result also supports the analysis as mentioned before where the firms main source of financing was not from bond market and it was from equity market, as the consequence they did not have high leverage problem. Comparing to regression of ROA (Equation 1), result on TQ is consistent except CLTAR is significant in ROA equation but not significant in TQ equation.

The regression equation for Equation 2 (TQ) for wholesale \& retail is as below:

$\mathrm{TQ}=-0.076+0.315$ CATAR $-0.008 S L G R-0.001 L E V+0.043$ CLTAR +0.189 SIZE

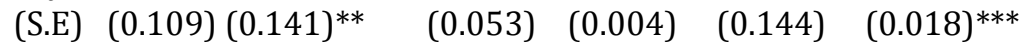

${ }^{* * *}$ indicates significant at $1 \%,{ }^{* *}$ significant at $5 \%$; S.E. is standard error, Adjusted R square is 0.095 and Fstats significant at $1 \%$ level)

The regression equation for Equation 2 (TQ) for property industry is as below:

$\mathrm{TQ}=-0.087+0.300$ CATAR $-0.005 S L G R+0.00018 L E V-0.027$ CLTAR +0.086 SIZE

$\begin{array}{lllll}\text { S.E) }(0.063) \quad(0.044)^{* * *} \quad(0.003) & (0.000)^{* *} & (0.012)^{* *} & (0.009)^{* * *}\end{array}$

(** indicates significant at $1 \%,{ }^{* *}$ significant at $5 \%$; S.E. is standard error, Adjusted R square is 0.16 and Fstats significant at $1 \%$ level)

Result from wholesale \& retail regression is consistent with results from combine both wholesale \& retail and property, where CATAR and SIZE are positive and significant while SLGR, LEV and CLTAR are not significant. For property industry, both LEVR and CLTAR are significant at $5 \%$ level. As comparison for wholesale \& retail results, three independent variables (SLGR, LEV and CLTAR) are significant in ROA equation but not in TQ equation. Meanwhile, LEV is significant in TQ equation regression for property industry but not significant in ROA equation regression.

\section{Conclusion}

This study examines the impact of the WCM on firm's performance. The two components of working capital are the independent variables which include Current Assets to Total Assets Ratio (CATAR) and Current Liabilities to Total Assets Ratio (CLTAR). Firm's performance is measured by both the profitability known as Return on Assets (ROA) and market value known as Tobin's Q (TQ). There are three independent variables correlated to firm's working capital and profitability is included in this study as well and consists of Firm Size (SIZE), Sales Growth (SLGR) and Financial Leverage (LEV). CATAR and SIZE are found to be the most consistent variables because both the CATAR and SIZE proven positive influence on the organisation's performance (ROA and TQ) from the (i) combination of wholesale \& retail and property industry, (ii) wholesale \& retail industry and (iii) property industry. This signal provide a large extent on the evidence that both wholesale \& retail and property industries are adopting conservative investment strategy to expand the business and this stability indeed assisting Malaysia to grow consistently to achieve as a developed country. CLTAR is also considered consistent because CLTAR also has significant positive or negative impact on the firm's performance (ROA and TQ) from the combination of wholesale \& retail and property industry, wholesale \& retail industry and property industry except for the TQ from the combination of wholesale \& retail products and property industry which shows insignificant impact. LEV only has significant negative impact on firm's profitability (ROA) from wholesale \& retail industry and significant positive impact on firm's market value (TQ) from property industry while impact on the others is insignificant. Finally, SLGR has significant positive impact on the ROA of the firm.

This study will lead to an identification and understanding of impact of WCM on firm's performance, particularly for wholesale \& retail industry and property industry in Malaysia public listed companies. The goal and objective of a firm is to maximize profits and create value for their shareholders. Thus, managers should adopt strategies that that have positive impact on the firm's performance. Besides, managers should reduce the tactics that will cause terrible consequence on the performance of the organisation. As a conclusion, the overall results of this study imply that Malaysian firms should pursue a prudent investment strategy by maintaining high level of investment policy in short term in order to increase firms' performance. However, following investment strategy with aggressive method via long term investment will cause Malaysian firms to have their profitability and value to depreciate. Overall results of this study also implicate that larger Malaysian firms presumed to support the yield of the profitability, thus larger Malaysia's organisations are profitable and can create more value for their shareholders. These results suggest that 
Malaysian firms should increase their size in order to have higher profits and create more value to their shareholders.

Recommendations: Future researcher can include firms from other industries as they may provide different results that can be used to compare against the results of this study. Furthermore, future study could include other dependent, independent, and control variables in their studies to investigate more variables that could have significant impact to the WCM.

\section{References}

Alam, H. M., Ali, L., Rehman, C. A. \& Akram, M. (2011). Impact of Working Capital Management on Profitability and Market Valuation of Pakistani Firms. European Journal of Economics, Finance and Administrative Sciences, 32, 48-54.

Afeef, M. (2011). Analyzing the Impact of Working Capital Management on the Profitability of SME's in Pakistan. International Journal of Business and Social Science, 2(22), 173-183.

Azam, M. \& Haider, I. (2011). Impact of Working Capital Management on Firm's Performance: Evidence from Non-Financial Institutions of KSE-30 index. Interdisciplinary Journal of Contemporary Research in Business, 3(5), 481-9492.

Charitou, M., Lois, P. \& Santoso, H. B. (2012). The Relationship between Working Capital Management and Firm's Profitability: An Empirical Investigation for an Emerging Asian Country. International Business \& Economics Research Journal, 11(8), 839-848.

Deloof, M. (2003). Does Working Capital Management Affect Profitability of Belgian Firms? Journal of Business, Finance and Accounting, 30(3-4), 573-587.

Eljelly, A. M. A. (2004). Liquidity-Profitability Tradeoff: An Empirical Investigation in An Emerging Market. International Journal of Commerce and Management, 14(2), 48-61.

Hussain, A., Farooq, S. U. \& Khan, K. U. (2012). Aggressiveness and Conservativeness of Working Capital: A Case of Pakistani Manufacturing Sector. European Journal of Scientific Research, 73(2), 171-182.

Kaddumi, T. A. \& Ramadan, I. Z. (2012). Profitability and Working Capital Management: The Jordanian Case. International Journal of Economics and Finance, 4(4), 217-226.

Kargar, J. \& Blumenthal, R. A. (1994). Leverage Impact of Working Capital in Small Businesses. TMA Journal, 14(6), 46-53.

Lazaridis, I. \& Tryfonidis, D. (2006). Relationship between Working Capital Management and Profitability of Listed Companies in the Athens Stock Exchange. Journal of Financial Management and Analysis, 19(1), 26-35.

Mona, A. M. (2012). The Impact of Working Capital Management Policies on Firm's Profitability and Value: The Case of Jordan. International Research Journal of Finance and Economics, 3(2), 147-153.

Napompech, K. (2012). Effects of Working Capital Management on the Profitability of Thai Listed Firms. International Journal of Trade, Economics and Finance, 3(3), 227-232.

Nazir, M. S. \& Afza, T. (2009). Impact of Aggressive Working Capital Management Policy on Firms' Profitability. The IUP Journal of Applied Finance, 15(8), 19-30.

Peel, M. L. \& Wilson, N. (1996). Working Capital and Financial Management Practices in Small Firm Sector. International Small and Business Journal, 14(2), 52-68.

Pouraghajan, A. \& Emamgholipourarchi, M. (2012). Impact of Working Capital Management on Profitability and Market Valuation: Evidence from Tehran Stock Exchange. International Journal of Business and Social Science, 3(10), 311-318.

Ray, S. (2012). Evaluating the Impact of Working Capital Management Components on Corporate Profitability: Evidence from Indian Manufacturing Firms. International Journal of Economic Practices and Theories, 2(3), 127-136.

Raheman, A., Afza, T., Qayyum, A. \& Bodla, M. A. (2010). Working Capital Management and Corporate Performance of Manufacturing Sector in Pakistan. International Research Journal of Finance and Economics, 47, 151-163.

Raheman, A. \& Nasr, M. (2007). Working Capital Management And Profitability - Case Of Pakistani Firms. International Review of Business Research Papers, 3(1), 279-300.

Sanger, J. S. (2001). Working Capital: A Modern Approach. Financial Executive, 69(1). 
Shin, H. H. \& Soenen, L. (1998). Efficiency of Working Capital Management and Corporate Profitability. Financial Practice and Education, 8(2), 37-45.

Smith, K. (1980). Profitability versus Liquidity Tradeoffs in Working Capital Management. In Readings on the Management of Working Capital, West Publishing Company, St. Pail, New York, 1880.

Teruel, P. J. G. \& Solano, P. M. (2007). Effects of Working Capital Management on SME Profitability. International Journal of Managerial Finance, 3(2), 164-177.

Usama, M. (2012). Working Capital Management and its affect on firm's profitability and liquidity: In Other food sector of (KSE) Karachi Stock Exchange. Arabian Journal of Business and Management Review (OMAN Chapter), 1(12), 62-73.

Vahid, T. K., Mohsen, A. K. \& Mohammadreza, E. (2012). The Impact of Working Capital Management Policies on Firm's Profitability and Value: Evidence from Iranian Companies. International Research Journal of Finance and Economics, 88, 155-162.

Zariyawati, M. A., Annuar, M. N., Taufiq, H. \& Abdul Rahim, A. S. (2009). Working Capital Management and corporate performance: Case of Malaysia. Journal of Modern Accounting and Auditing, 5(11), 47-54.

Afiq, S. (2011). The Retail Market in Malaysia. Property Quotient. Retrieved March 29th, 2013, from http://www.malaysiapropertyinc.com/pdf/

JabatanPerdanaMenteri. (2012). Economic Transformation Programme Annual Report 2012. Retrieved July $23^{\text {th }}, 2013$ from http://etp.pemandu.gov.my/annualreport2012/

JabatanPerdanaMenteri. (2010). Government Transformation Programme: The Roadmap. Retrieved April $23^{\text {th }}, 2012$ from http://jpt.moe.gov.my/eng/RUJUKAN/GTP\%20Roadmap.pdf

Nor, Z. A., Nurhisham, H. \& Afiq, A. M. (2013). The 2012 Bank Negara Malaysia Annual Report. Malaysian Rating Corporation Berhad Economic Research. Retrieved May 18 ${ }^{\text {th }}, 2013$ from http://www.marc.com.my/home/userfiles/file/210313_BNM\%20Annual\%20Report\%202012_Final .pdf. 